\title{
The Correction of Post-Keratoplasty Astigmatism
}

\author{
N. C. PRICE and A. D. McG. STEELE \\ London
}

\begin{abstract}
Summary
The results of refractive surgery for post-keratoplasty astigmatism in 41 eyes are presented. Thirty-nine eyes regained a functional vision of $6 / 12$ or better.

Relieving incisions and compression sutures are the most useful procedures, but more than one operation may be required.
\end{abstract}

The mean corneal astigmatism after penetrating keratoplasty is between 2 and 5 dioptres (unpublished data), and this degree of error is normally overcome using spectacle or contact lens correction.

High degrees of post-keratoplasty astigmatism occasionally render clear corneal grafts functionally useless with the patients intolerant of all optical aids.

Surgical techniques to steepen the flat meridian of an astigmatic cornea were described in the last century by Lans, ${ }^{1}$ who used cautery, and in the 1950 s by Poyales $^{2}$ and Barraquer, ${ }^{3}$ who described wedge resections of cornea and sclera.

Snellen ${ }^{4}$ undertook a form of anterior corneal relieving incisions in 1869 to flatten the steep meridian, and Bates ${ }^{5}$ left wedge resections unsutured to induce the same effect. Sato $^{6}$ reported posterior corneal relieving incisions in 1950.

Modern microsurgical refinements of these techniques were introduced by Troutman ${ }^{7.8}$ in the mid 1970s, and following his work corneal surgeons have re-explored the possibilities of surgically altering the astigmatic cornea.

The recent results of surgery for post keratoplasty astigmatism performed on selected patients attending the Corneal Clinic of Moorfields Eye Hospital are presented.

\section{Material and Method}

A 4-year retrospective analysis of all patients undergoing surgery for post-keratoplasty astigmatism has been undertaken.

All patients had clear corneal grafts but functional vision of less than $6 / 60$ due to intolerance of spectacle or contact lens correction.

Astigmatism was determined by refraction and confirmed by keratometry.

Various methods of treatment were used, the most common being relieving incisions; two incisions were made, opposite one another, in the steep axis of the cornea. Each incision extended for 60 to 90 degrees of the circumference of the graft-host interface, and was made to at least 75 per cent of corneal depth (Fig. 1). In some patients the effect of relieving incisions was increased by placing tight $9 / 0$ or $10 / 0$ nylon sutures across the graft-host interface at 90 degrees to the incisions. The sutures were removed some weeks after surgery.

Wedge resection, in which the flat meridian was steepened by excision of a wedge of tissue and the gap closed by tight sutures, gave wildly varying results in our hands and was soon abandoned in favour of compression sutures. Compression sutures were placed along the flat axis, across the graft host interface and tied tightly, causing steepening of the cornea in that meridian in the same way as a wedge resection. It is our practice initially to over correct the astigmatism by the placement of up to four $9 / 0$ nylon sutures on each side of the graft, over 45-60 degrees of the graft circumference (Fig.

Correspondence to: Mr. A. D. McG. Steele, FRCS. FRACO; Moorfields Eye Hospital, City Road, London EC1V 2PD.

Presented at the Annual Meeting of the Ophthalmological Society of the United Kingdom, April 1987. 
Refraction $-6.00 \times 90^{\circ}$

Shape of cornea
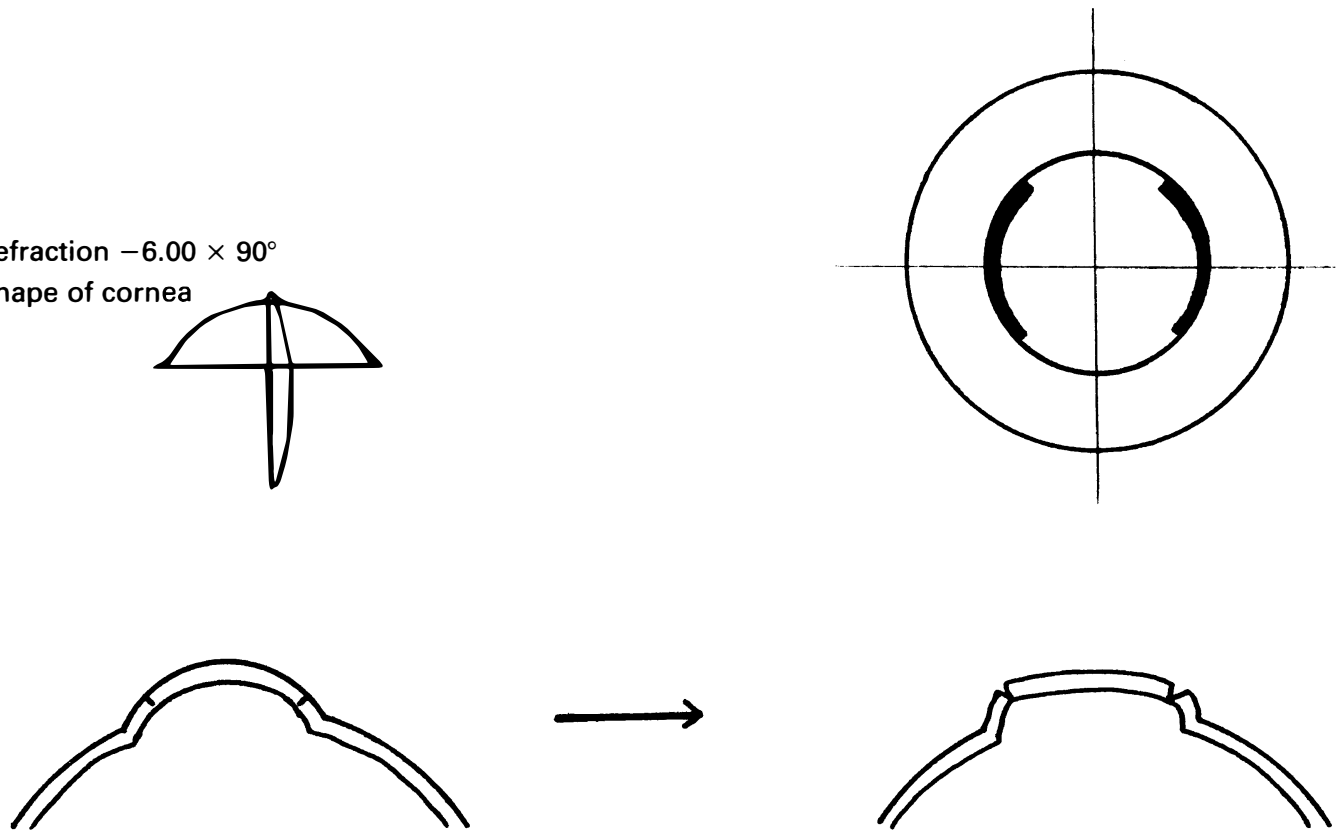

Fig. 1. Relieving incisions.

2), and to adjust the correction by selective removal of sutures over the succeeding few weeks.

We have not found it possible accurately to relate correction achieved to length of suture bite or number of sutures, so have always aimed at initial obvious over correction.
Refraction $+6.00 \times 90^{\circ}$

Shape of cornea
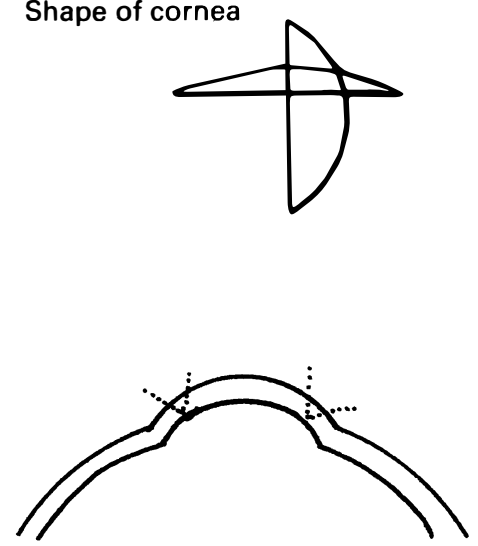
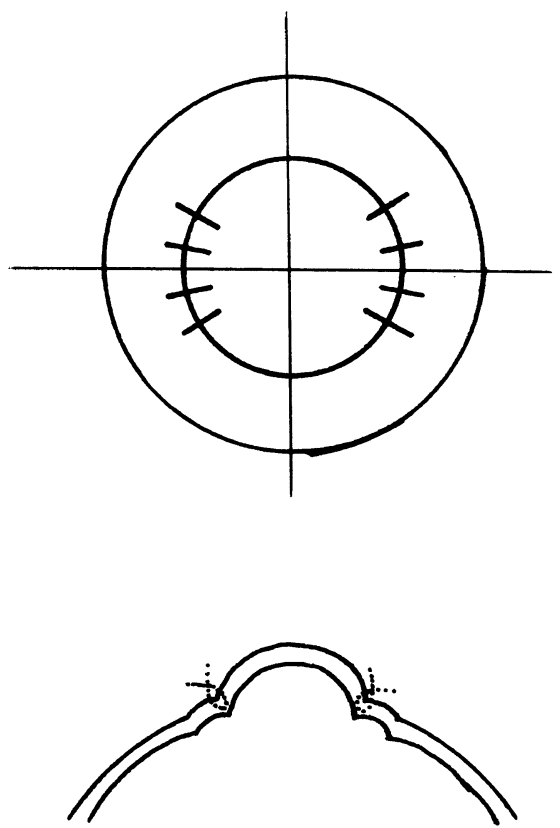

Fig. 2. Compression sutures. 


\section{Results}

Forty-one eyes of 39 patients have been treated over the past 4 years, with a sex and age distribution as shown, (Table I). Two thirds of the patients had been grafted for keratoconus, (Table II).

Table I. Age and sex distribution of patients

\begin{tabular}{crc}
\hline Age & & \\
\hline Unknown & 2 & \\
$18-29$ & 12 & \\
$30-39$ & 11 & Male $=14$ \\
$40-49$ & 7 & \\
$50-59$ & 1 & \\
$60-65$ & 1 & \\
$66+$ & 5 & \\
\hline
\end{tabular}

Table II. Original pathology

Keratoconus

Bullous Keratopathy

Fuchs Dystrophy

HSV

Suppurative Keratitis

Table III shows that an average of 6 dioptres of astigmatism were relieved by surgery. The useful visual acuity, either corrected or uncorrected, had improved from less than $6 / 60$ in all cases to $6 / 12$ or better in 39 out of 41 eyes, (Table IV).

Table III. Initial vs final refraction

\begin{tabular}{lll}
\hline & Sphere $( \pm S D)$ & Cylinder $( \pm S D)$ \\
\hline Initial & $+2.16 \pm 3.96$ & $-9.71 \pm 2.0$ \\
Final & $+0.21 \pm 4.1$ & $-3.77 \pm 2.16$ \\
\hline
\end{tabular}

Table IV. Final functional acuity

Greater than or equal to $6 / 6$ $6 / 9-6 / 12$

$<6 / 12$

10

29

2

The total number of procedures required to provide stable useful vision was 67 , (Table V) but 22 of 41 eyes required only one procedure: relieving incisions in 18 cases, and refractive sutures in 4, (Table VI).
Table V. Total Operations

Relieving incisions 37

Relieving incisions \& sutures opposite axis 2

Compression sutures $\quad 13$

Re-open wound \& compression sutures 8

Wedge resection 6

Re-trephine \& re-suture $\quad \frac{1}{67}$

Table VI. Number of procedures per patient

\begin{tabular}{cc}
\hline Number & Patients \\
\hline 1 & 22 \\
2 & 11 \\
3 & 7 \\
4 & 0 \\
5 & 0 \\
6 & 1 \\
\hline
\end{tabular}

The mean time to final acuity was 7.2 months from the start of surgery, but 11.8 months if more than one procedure was required. Many patients achieved useful vision before refractive stability was attained, (Table VII) defined as a stable refraction on at least two visits separated by at least four weeks.

Table VII. Time to final acuity \& refractive stability

\begin{tabular}{ccc}
\hline months & $\begin{array}{c}\text { Patients achieving } \\
\text { final VA }\end{array}$ & $\begin{array}{c}\text { Patients achieving } \\
\text { stable refraction }\end{array}$ \\
\hline $0-6$ & 30 & 22 \\
$7-12$ & 3 & 8 \\
$13-18$ & 4 & 4 \\
$19-24$ & 0 & 1 \\
$25-30$ & 1 & 2 \\
$31-36$ & 3 & 4 \\
\hline
\end{tabular}

There was considerable variation in the results of any given procedure, as reported in all previous papers, but Table VIII shows the mean reduction in astigmatism produced, which compares well with reported series. ${ }^{8-11}$ Complications are listed in Table IX.

\section{Discussion}

Our results, as well as those of other authors $^{7-11}$ indicate that almost all patients with high degrees of post-keratoplasty astigmatism can be significantly helped by refractive surgery. The surgery is of particular benefit as it rehabilitates patients who are mainly of working age. 
Table VIII. Effects of procedures

\begin{tabular}{lccc}
\hline Procedure & Number & $\begin{array}{c}\text { Change in sphere } \\
( \pm S D)\end{array}$ & $\begin{array}{c}\text { Change in cyl } \\
( \pm S D)\end{array}$ \\
\hline Relieving incision & 37 & $-2.01 \pm 3.20$ & $4.49 \pm 6.22$ \\
Compression sutures & 13 & $-2.39 \pm 3.16$ & $6.50 \pm 5.31$ \\
$\begin{array}{l}\text { Re-open wound \& } \\
\text { compression sutures }\end{array}$ & 8 & $-4.1 \pm 5.97$ & $5.80 \pm 7.23$ \\
\hline
\end{tabular}

Table IX. Complications

\begin{tabular}{lcl}
\hline Complication & Number & Comment \\
\hline Perforation & 8 & 5 pad \\
& & 1 lens \\
Rejection & 1 & Medical treatment \\
\hline
\end{tabular}

Like other forms of refractive surgery, all the techniques used are unpredictable, in the degree of correction obtained by a single procedure. With the exception of wedge resection, however, we found them to be effective.

Relieving incisions are simple surgical procedures and the patient achieves his final correction within a few weeks of surgery.

The deliberate over correction normally induced by compression sutures leads to a period of poor vision but after 2-3 months the over correction can be reduced by selective suture removal. Our results show no significant benefit from reopening the wound prior to the placement of compression sutures and this is probably unnecessary in most cases.

Refractive procedures such as these do not offer over-night correction, as can be seen from the number of procedures required, and the time taken to achieve a stable refraction. Half of the patients were corrected by one procedure, but a few were difficult to manage and required several operations. Follow up times are relatively short, but we have found no significant change in refraction once stability has been achieved. One may anticipate that any procedures requiring sutures will need adjustment as the sutures degrade. 9/0 nylon lasts significantly longer than $10 / 0$ before degradation, and is used routinely for compression sutures.

Other procedures requiring multiple incisions have been described ${ }^{12}$ as alternative to those used in our cases. These complex procedures seem no more reliable than relieving incisions and compression sutures at present. ${ }^{13}$ We have avoided techniques which involve incisions into the host stroma outside the graft limits, since such refractive techniques may prejudice the chances of future keratoplasty by inducing vascularisation or weakening the host tissue.

In our view, relieving incisions and compression sutures are the methods of first choice, and can be applied to all patients who, following graft suture removal and unsuccessful trial of spectacles and/or contact lenses, are left with an unmanageable degree of corneal astigmatism.

Complications were uncommon, and did not affect the final visual outcome in any cases. Five of the perforations were so small that padding alone sealed the leak overnight, while two were sutured at the time of surgery. One rejection episode occurred 2 weeks after re-opening a wound with placement of compression sutures, but rapidly resolved on medical treatment.

With the exercise of care and patience, most patients can achieve useful vision following refractive surgery. It is no longer acceptable to regard, as untreatable, a patient who has a clear graft, but who is unable to use it because of high post keratoplasty astigmatism.

\section{References}

${ }^{1}$ Lans LJ: Experimentelle Untersuchungen uber die Entstehung von Astigmatisums durch nicht-perforirende Corneawunden. Albrecht Von Graefes Arch Klin Exp Ophthalmol 1898, 45: 117-52.

2 Poyales I: Actas I Congreso Oftalmologico Latino Rome. Arte della Stampa 1953.

${ }^{3}$ Barraquer $\mathbf{J}$ and Muinos A: Lamellar scleral resection: indications and technique. $A m J$ Ophthalmol 1956, 41: 92-8.

${ }^{4}$ Snellen H: Die Richtung der Hauptmeridiane des astigmatischen Auges. Albrecht Von Graefes Arch Klin Exp Ophthalmol 1869, 15: 199-207. 
${ }^{5}$ Bates WH: A suggestion of an operation to correct astigmatism. Arch Ophthalmol 1894, 23: 9-13.

${ }^{6}$ Sato T: Posterior incision of cornea. Am J Ophthalmol 1950, 33: 943-8.

7 Troutman RC: Microsurgical control of corneal astigmatism in cataract and keratoplasty. Trans Am Acad Ophthalmol Otolaryngol 1973, 77: 563-72.

${ }^{8}$ Troutman RC: Microsurgery of the anterior segment of the eye. St Louis, CV Mosby 1977: 286.

${ }^{9}$ Krachmer JH and Fenzl RE: Surgical correction of high post-keratoplasty astigmatism. Arch Ophthalmol 1980, 98: 1400-2.
${ }^{10}$ Roper Hall MJ: Control of astigmatism after surgery and trauma. Br J Ophthalmol 1982, 66: 556-9

${ }^{11}$ Lavery GW, Lindstrom RF, Hofer LA, Doughman DJ: The surgical management of corneal astigmatism after penetrating keratoplasty. Ophthal Surg 1985, 16: 165-9.

12 Lavery GW and Lindstrom RL: Trapezoidal astigmatic keratotomy in human cadaver eyes. $J$ Refract Surg 1985, 1: 18-24.

${ }^{13}$ Merck MP, Williams PA, Lindstrom RL: Trapezoidal Keratotomy. A vector analysis. Ophthalmol 1987, 93: 719-26. 